\title{
SYRIAN CIVIL WAR IN INTERNATIONAL PERSPECTIVE
}

Prof. Dr. Syed Salahuddin Ahmed, Professor of International Relations, Greenwich University, Karachi - Pakistan.

Email address: ahmadsyedslahuddin@gmail.com

Dr. Syed Shahabuddin, Assistant Professor, Department of International Relations, Federal Urdu University, Karachi - Pakistan Email address: shahabhashmi2012@gmail.com

\begin{abstract}
The Syrian civil war in the subject matter of international concern. This bloodiest war directly hits the main objectives of the United Nations Security Council i.e. maintenance of international peace and security. What is extremely surprising is that the state on whose shoulder lies the maintenance of permanent peace are directly involved in this holocaust. The United State, U.K. and France and other Western countries are parties to this conflict versus Russia, China and other countries. Instead of playing active role for the restoration of peace, these major powers have ripped the chances of peace and ignited the war flames. This study will attempt to find the answers of some of the pertinent questions around which the central theme of this paper revolves. The pertinent questions are for example what are the root causes of this war? Who are belligerents or actors? Who is fighting against whom> who are the main victims of this war? The causes of the internal strife and tensions in the Muslims World will be discussed. The nature of the repercussion of the Arab Spring uprising will highlighted. Another objective of this study is to assess and foretell the consequences of the end of this war. Wars end in the victory of one party or parties and defeat of another party or parties and sometimes however it ends in stalemate. We will try to assess what will be the repercussions of this war in all its ramifications when it ends and how its ends. Our research will focus on the phenomenon of what will be impact on the world, if the main belligerent Bashar Al Assad capitulates or removed from power.
\end{abstract}




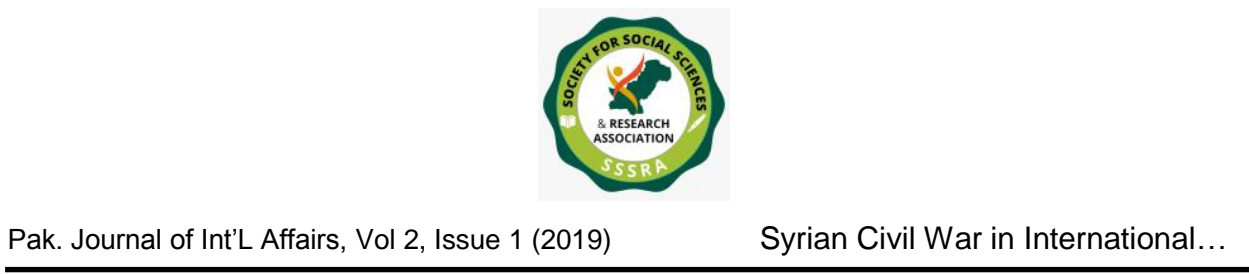

Keywords: Civil War, International Peace, Belligerent, Muslim World, Arab Spring Ramifications, Repercussions

\section{INTRODUCTION}

The Syrian civil war is the subject matter of international concern. This bloodiest war directly hits the main objective of the United Nations Security Council i.e. maintenance of international peace of security. What is extremely surprising is that the states on those shoulders lies the maintenance of permanent peace are directly involved in this holocaust. The United States, U.K. and France and other Western countries are parties to this conflict versus Russia, China and other countries. Instead of playing active role for the restoration of peace, these major powers have ripped the chances of peace and ignited the war flames.

Public generally in Pakistan and particular the intelligentsia is ill informed about the facts and figures of the Syrians Civil War. Abundance of fabricated news on TV and radio has misinformed the masses. Students and professors are less informed about the global ramifications of war. There is dire need of in-depth, objective and fair study of the, causes, nature and belligerents of this war.

The Syrian civil war raises many questions about the sensibility and perceptivity of the foreign policy objectives and behavior of the world powers. It seems they have lost all sense of morality and indulged in the lust for power. In this article we will not try to prove or disprove any hypothesis. No data will be collected and no statistical method will be used. About seven billion people live in this world and they are all human being. This world is not a business entrepreneur. The subject matter and the scope of this world is beyond business. Statistics does not solve human sufferings, agonies, human liking and disliking, passion, emotion, preferences and values, love and hate phenomenon. This study basically will be analytical, behavioral and descriptive. 


\section{PROBLEM STATEMENT}

Syrian Civil War has become complex. Too many actors are involved. The objectives of the belligerents among themselves of one side are opposed and contradictory. The problem of adversary is compounded with changing environment and war objective. It is not a civil war as is defined in the dictionary of the political science or international relations. And since many belligerents are involved with so many different diametrically opposed objective, it is difficult to predict any phenomena or any results, if hostilities cease.

\section{RESEARCH OBJECTIVES}

No clear cut or apparent result is expected after the end of the civil war. However we will to endeavor to find:-

1. What will be the consequences of the war in the region and in the world, if ASSAD, the main actor capitulates?

2. What will be repercussion, if the stalemate continues?

3 . What will be the impact if armistice is signed between the belligerents with no victors and no vanquished?

Another objective of this study is to assess and foretell the consequences of this war. The war end in the victory of one part or parties and the defeat of another party or parties and sometimes however it ends in stalemate. We will try to assess what will be the ramifications of this war when it ends and how it ends. Our research will focus on the phenomenon of what will be repercussions if the main belligerent Bashar Al Assad capitulates or is removed from power.

\section{RESEARCH METHOD}

This study basically will be analytical, behavioral and descriptive. We will not try to prove or disprove any hypothesis in this paper. No data will be collected and no statistical method will be applied. The world in a broader meaning is not a business world. Its subject matter is beyond business. We 


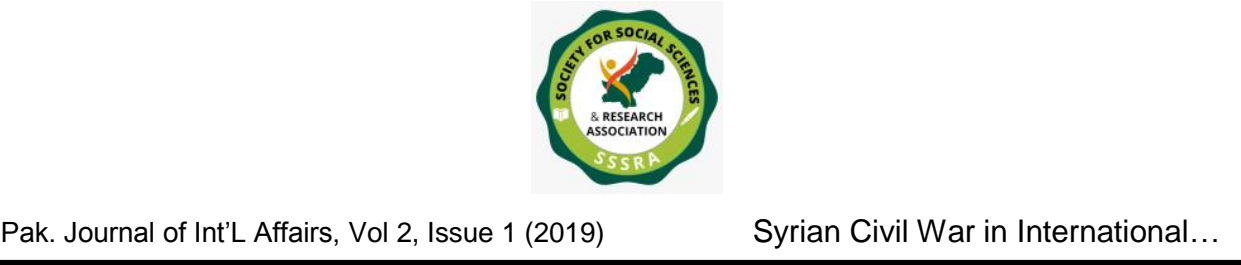

are discussing human problems. What is at stake in this research is human value.

\section{LITERATURE REVIEW}

Erlich (2016) with a foreword by foreword by Noam Chomsky deals with the Backstory of the Civil War and expresses what the world can expect. It is an essential guide in navigating the political winds of the Syrian war.

Andrews (2016) "present an understanding of the world's trouble spots. The author elaborates the causes and effects every conflict in the world and also presents its historical context.

Said (1992) beautifully portrays Palestinian Problem in his world famous book, "The Question of Palestine (1992)". Though the book was written 25 years ago yet no book on Palestine issue can compete its authenticity about the role and miseries of the Palestinian people be they in Ghaza, West Bank, Jordan, Lebanon and Syria.

Ahmad (2005) in his book "Foreign Policy of Pakistan (2005)" evaluates U.S. War on Terrorism meaning a war against Al-Qaeda be it in Pakistan, Afghanistan, Iraq, Somalia, or Syria. This is one of the reasons why U.S. justifies its belligerent role in Syrian civil war.

Brunet-Jaily (2015) in her book, "Global Encyclopedia on the Border Disputes, Vol.1 2015) writes that after even three wars, there has been no breakthrough in the peace process. To this day Golan Heights remains disputed. Occasionally Israeli missiles hit Syrian targets.

Ahmad and. Shaikh (2007) analyzed and discussed the term "Terrorism". In their thought provoking article, "Terrorism: A Grim Challenge to Social Sciences, (Spring 2007)" asserted that "There is no denial of fact that the United States has been using this phenomenon of terrorism as a tool in the execution and achievement of her foreign policy objectives." It is on this pretext that the U.S. has assumed a belligerent role in the Syrian civil war. This time its avowed targets are ISIS and Al-Qaeda in side Syria. 
Warrick, Joby (2016) presents most thorough account of the rise and growth of ISIS in his work "Black Flags: the rise of ISIS." He enumerates all events of the civil war with the actual and potential and influence of various actors in the catastrophe.

Stern, Jessica and Berger J.M. (2016) portrayed a brisk, readable and eye opening account of ISIS in Iraq and Syria. It is a Penetrating analysis.

This study will attempt to find the answers of some of the pertinent questions around which the central theme of this paper revolves. The pertinent questions are for example what are the root causes of this war? Who are the belligerents or actor? Who is fighting against whom? Who are the main victims of this war? The causes of the internal strife and tensions in the Muslims World will be discussed. The nature of the repercussion of the Arab Spring uprising will be highlighted.

\section{BACKGROUND OF THE CIVIL WAR}

\section{ARAB SPRING UPRISING}

On December 17, 2010 a Tunisian vendor Muhammad Bouazizi immolated himself initiating Tunisian Uprising and eventually Arab Spring Uprising. Since then Tunisia has made great stride In the region toward achieving its goal.

In early 2011 the Tunisian uprising inspired similar protests in Egypt, Yemen, Saudi Arabia, Bahrain and other Middle East countries. Conditions were ripe in Syria as well. Poverty and unemployment were on the rise (Erlich. 2016) People lived under a dictatorial regime whose criticism of the government meant jail and torture. President Assad believed that Syrians would never rebel against a pan-Arabist, anti-lsrael and anti-imperialist fighter. Quickly he was proven wrong. The antigovernment demonstration began in the Southern city of DARAA in March 2011 (P.82). 
By mid-March demonstration broke out in Damascus. Protestors were peaceful. Assad cracked down the protestors mercilessly. The main opposition groups called for the overthrow of Assad' government. Daraa governor and other officials blamed that extremists seized control of the demonstrations. They accused that the agitators were armed and paid by Saudi Arabia and Qatar.

The demonstrators were politically and militarily backed by Israel, the United States and Euro, as a result over 1200 police, army and other security personnel had been killed by the demonstrators (Erlich, p. 84.)

The opposition movement grew. They included leftists, liberals, seculars and Muslims who are regarded as conservatives. They developed an alliance. They were united on the need to overthrow Assad, hold free elections, establish parliamentary system, with civil liberties.

In July 2011 defectors from the Syrian army announced formation of FREE SYRIAN ARMY (FSA). Both sides were engaged in target assassination On October 2, 2011 son of Syria's grand mufti was killed. On October 7, 2011 Kurdish Leader Mashaal Tammo was killed by government forces.

The United States, Turkey, Saudi Arabia and Qatar supported the FSA. In December 2012 the FSA whom the United States had given \$ 15 million as logistic aid, announced the formation of Supreme Military Council which would try to coordinate all militias in Syria. Among the opposition groups each has its own motive to fight. They are not united about the objective after the war ended.

\section{BELLIGERENTS:}

A cursory look at the theatre of war presents a picture of war in which big powers like the United States, Britain, France and Germany are pitched against the Russia, Iran and the Syrian Republic The roles of ISIS, AlQaeda, rebel groups in Syria, Saud Arabia, other Arab countries and Turkey cannot be ignored. There are so many actors involved in this 
bloody war that some observers call it international war. The situation has been further aggravated by the internal fractions and discords among the various groups of rebels in Syrian Republic. They are engaged in a war against Bashar Al Asad regime.

Western Coalition Countries (fighting against Bashar Al Asad Regime) United States, Australia, Denmark, Netherland, France, Germany, U.K. Canada (for some time) Pro-Western Coalition Arab Countries:- Jordan, Iraq (Kurd), Saudi Arabia, Qatar, Bahrain, UAE.

Syrian Rebels

fighting against Bashar Al Asad:- Syrian Democratic forces (mostly Kurds) Syrian Military Council, Free Syrian Army.

The following Belligerents are against the Western Coalition but they are also fighting against The Syrian Arab Republic.

ISIS (DAISH) The term needs no explanation here. It is known as Islamic State for Iraq and Sham (Syria). It is recently established caliphate which is losing ground figuratively and physically. The United States regards this state as the terrorist state.

Al-Qaeda, the notable organization which is accused by the United States as a terrorist Organization and is also accused for bombing the twin towers in Ney York.

Al Nusra Front. It is officially banished. ISIS has taken it place. Saudi Arabia, Kuwait and other gulf states have been providing arms and financial help to this organization Thousands of ISIS supporters have been recruited from the North African and Gulf States.

Ahrar al Sham is one of the largest militia in Syria. It was founded in 2011 by conservative leaders. Literarily it means Islamic Movement of the Freemen of Levant. It is influential in the provinces near the Turkish 


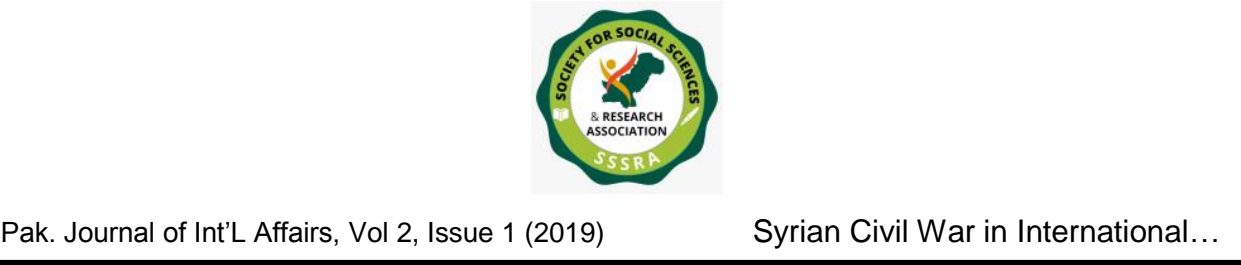

border. AL Sham seeks to over throw the ASSAD regime and establish an Islamic State.

\section{THE ROLE OF KURDS}

The Kurds are not concentrated in Syria alone. They are dispersed in Turkey, Iraq and Iran. They have separate cultural and language. In each country they are demanding greater autonomy. History has proven their valor and bravery. Great Crusader Salahuddin was a Kurd. They make up an estimated 10 to 15 percent of Syria's 22.5 million populations, At the time of 2011 Arab Spring uprising Kurds opposed Assad's dictatorship. Hundreds of thousands Kurds fled from Syria because of fighting. According to some reports in the 1960s and 1970's there were plans and efforts to unite the Kurds of Syria, lraq and Turkey to create a Separate idea. Kurd state. None of these states nor the world public opinion supported such an Therefore it had to be buried. Each state brutally crushed Kurd movements.

During the period of civil war, the Kurds in Syria organized themselves and opposed the Syrian regime. The Kurd leaders joined the opposition forces against Assad. The Democratic Union Party (PYD) was the first of the Kurdish groups to take up armed struggle in ROJAWA-northern region of Syria (Erlich, P.182). The problem with the Kurds is that they do unite with any faction engaged in war against Assad. Sometimes they fight with other opposition groups such as Free Syrian Army and other Islamic groups.

This is 21 century. Twentieth century "Cold War" has now become history. It is said History repeats itself. History is being repeated now in Syrian Civil War. The actors of cold war are now actively involved in this war and have turned it into a hot war. Indeed it is now a ferocious war. Another feature of this war is that Saudi Arabia and Iran are fighting in opposite camps. Saudi

Arabia claims and is regarded as the leader of Sunni World of Islam while Iran is leading Shia 
World of Islam. Some atheists and secular minded Muslim critics call this war as Sunni-Shia war. Some say it is a proxy war between Iran and Saudi Arabia. (the above details have been retrieved from Wikipedia).

\section{USE OF CHEMICAL WEAPONS}

On August 21.2012 a chemical bomb was dropped in the town of $\mathrm{Al}$ Ghouta near Damascus. It was, experts say, SARIN GAS. The death too was reported to be 1429. Syrian army and the rebels accused each other for the use of chemical weapons. World reacted with anger and indignation. The U.S. condemned the ASSAD regime.

It was believed that by using chemical weapons the rebels would convince the U.S. that Assad regime is guilty. Therefore she will punish the regime by bombing Syrian targets. But the controversy spread soon and expert asked who used chemical weapon and why? Even the figure of the death was challenged. Other sources including Human Rights Watch counted only 502 deaths.

SARIN is a clear, colorless and tasteless liquid that has no odor in its true form. It is quite volatile and cannot be stored very long (ERLICH 2016,P105) The question is why the Syrian would attack its own people. The rebels particularly the ISIS, the Al Qaeda, Al Nusra would gain a lot from the use of chemical weapons. They will discredit the Assad regime, besides killing their enemies.

\section{WESTERN MISSILE ATTACK AGAINST THE USE OF CHEMICAL WEAPONS BY SYRIA}

According to CNN Broadcast, "Today the nations of Britain, France, and the United States of America have marshaled their righteous power against barbarism and brutality," said US President Donald Trump. Shortly after Trump's statement, UK Prime Minister Theresa May released a statement saying she had "authorized British armed forces to conduct coordinated and targeted strikes to degrade the Syrian Regime's chemical weapons capability and deter their use. 
"A statement released by the French President Emmanuel Macron, Friday, said that a "red line set by France in May 2017 has been crossed. So, I ordered the French armed forces to intervene tonight, as part of an international operation in coalition with the United States of America and the United Kingdom and directed against the clandestine chemical arsenal of the Syrian regime."

In announcing the strikes Friday, Trump said he had ordered "precision strikes on targets associated with the chemical weapon capabilities" of the Syrian regime

General Joseph Dun ford, Chairman of the Joint Chiefs of Staff, told reporters three sites were targeted:

- A scientific research center in Damascus.

- A chemical weapons storage facility, located west of Homs.

- A chemical weapons equipment storage facility and command post near Homs.

Syrian state TV said missiles targeting Homs were intercepted and did not cause damage, though $\mathrm{CNN}$ has been unable to verify this report.

Three civilians were wounded in Homs after 'several" missiles were intercepted by Syria air defense systems, Syria State TV said. Witnesses on the ground in Damascus reported hearing explosions in the Syrian capital, where more than a million people live.

(Retrieved from https:/ICNN.COM/2018/04/13/politics/Trump-ussyria/index.html)

\section{ARE THE STRIKES OVER?}

Trump said the US was "prepared to sustain this response until the Syrian regime stops its use of prohibited chemical agents," however, he maintained that "America does not seek an indefinite presence in Syria" 
At a Pentagon briefing. Dun ford said "this wave of airstrikes is over" but defense officials added they are prepared for a sustained campaign until the Syrian regime ceases its alleged use of chemical weapons.

Military and defense officials told CNN that at least one US Navy warship based in the Red Sea participated in Friday's strikes, as well as US B-I bombers.

A statement from the British Ministry of Defense said that four Royal Air Force Tornado GR4's were used in the strikes, launching Storm Shadow missiles at a "former missile base-some 15 miles west of Homs."

Dun ford said the US "specifically identified targets to "mitigate the risk of Russian forces being involved."

He added normal communication lines were used in the run-up to the strike to ensure clearance of airspace, but said targets were not coordinated with the Russians.

\section{HOW SYRIA AND RUSSIA RESPONDED?}

In a statement following the strikes, Anatoly Antonov, Russian ambassador to the US, said Moscow's "warnings have been le unheard."

We warned that such actions will not be left without consequences,' he said. "Insulting the President of Russia is unacceptable and inadmissible. The US -the possessor of the biggest arsenal of chemical weapons has no moral right to blame other countries."

In a statement posted on Facebook, Russia's Foreign Ministry spokeswoman, Maria Zakharova, said "After this statement the American and other Western mass media should understand their responsibility in what is happening."

\section{THE ROLE OF FOREIGN POWERS}




\section{PRO ASSAD BELLIGERENTS INCLUDE RUSSIA, IRAN AND HEZBOLLAH IRANI SUPPORT TO SYRIA}

Iranian support to Syria is nothing new. The two countries built a geopolitical alliance since 1979 Iranian revolution. The two countries adhered to different ideologies yet their enemies are common. They are united in opposition to Israel, the United States and Saudi Arabia. Another factor that brought them together was the hatred against Saddam Hussain of Iraq. Syrian rulers have regarded Bath Party of Iraq as a rival in the pursuit of leadership in the Arab world. In September 1980 Saddam Hussain had launched an attack on Iran. While the Arab with Iraq, Syria threw its support behind Iran. During the war, Iran sent one million barrels of free oil to Syria each year and eight million barrels at below market price. ( cited in ERLICH, P.148). Lebanese Shia militia HEZBOLLAH was formed, nurtured, trained and financially supported by lran. Later on Hezbollah proved to be a bulwark civil war, Hezbollah is playing active pro-Assad role in fighting against U.S., Israel.

During the past thirty five or forty years Iran and Syria also consolidated economic ties. Iran opened an automobile assembly plant, a cement plant and a power generating station. Iran's export to Syria increased from $\$ 35.7$ million in 2000 to S 387.4 million in 2010. Syrian export to lran increased twenty times (Erlich, P.149)

Whenever Syrian army faced military setbacks, Iran and Hezbollah stepped their support in terms of intelligence, training and finance. However Iran has refrained from sending any combat troops in Syria.

\section{THE ROLE OF SAUDI ARABIA, AND THE WEST}

Saudi Arabia has been supplying arms to Free Syrian Army and other rebel groups that follow Islamic ideology. Saudi policy is also against the Shia influence which has been implanted by Iranian involvement. The Ahrar al Sham the strongest rebel group received funding from Saudi Arabia. The Syrian government blamed Saudi Arabia that it had smuggled arms in Syria to support the rebels. The United States claims to be 


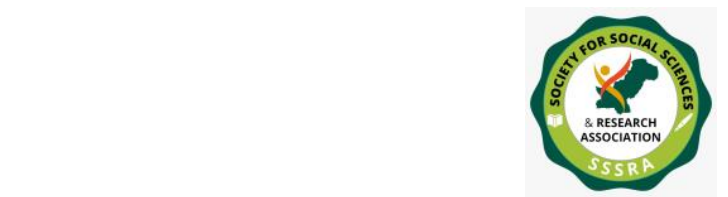

promoting moderate and secular rebels. Each foreign power by supplying arms to the rebels wants to carry out its political goal. The United States faces a major contradiction. Syrians either in the Syrian government or in rebel groups vehemently criticize the US policy for not pressurizing Israel to hand over GOLAN HEIGHTS to Syria. In fact they blame the United States for supporting and encouraging Israel to launch attack on Syria and doing enough to cease the hostilities in Syria. The US is also accused of not supporting rebels militarily so that Assad regime could capitulate.

\section{THE ROLE OF RUSSIA}

NO state in the world cares for human rights when it commercial benefits are challenged. Russia is supporting ASSAD in Syria because its commercial and military interests are involved. That Russia has supplied military weapons to Syria is no secret. In January 20131sraeli planes fired missiles at Syrian Convoy carrying Russian SA-17 antiaircraft missiles allegedly being delivered to Hezbollah (Erlich P.199)

Russia vetoed or threatened to veto every UN Security Council Resolution critical of Syria. Russia stepped up support for Assad regime in 20152016. Moscow wanted to maintain a military ally in the Middle East to block Washington's influence. (Erlich P.248). The Russian intervention prevented the US and the Western powers from establishing a no flying zone over Syria. (Erlich.P.249)

\section{PROJECTED SOLUTION TO THIS COMPLEX CIVIL WAR}

Now we turn to our main research objectives. There seems to be no military solution to the Syrian war. What will happen if Assad is overthrown or capitulates? Russia, Iran and Hezbollah will feel humiliated and defeated. The political and strategic influence of Russia and Iran in Syria and in the region will be greatly annihilated. Both Russia and Iran will never let it happen. The pertinent question is Bashar Al Assad will surrender to whom? Who is going to replace him and what authority will the successor possess? A possible solution which is acceptable, tangible, 10 durable, feasible and workable is an international agreement under 
auspices of the United actions, Under the term of the treaty all belligerents agree to

1. Accept and enforce immediate cease fire

2. A pledge from the parties not to violate the ceasefire

3. If any party violates the cease fire, it will be considered as an attack on all parties.

4. Assad has to be removed from power because Assad is autocrat, a despot and a dictator

5. There has to be an election free, fair and transparent under the auspices of the United

6. Nations Security Force or under some other international organizations.

7. All Syrian citizens be allowed to participate in the election. They must enjoy the right to vote and be voted upon. Gone are the days of dictatorship, kingship or one party rule.

8. Political parties be allowed to be formed, propagate their manifestos, run election campaign, enter into alliance

9. Even though there may be popularly elected legislature, all executive powers must be vested in a president.

10. There must be a constitutionally powerful Supreme Court with a view to creating a complete balance of power system.

11. Since more than 90 per cent of the population in Syria is Muslim, therefore Syria will declared an Islamic state. Laws enacted according to

12. The injunctions of Islam shall be the law of the land.

13. Religious laws and customs of the minorities shall be guaranteed.

14. Islamic, Arab Republic of Syria shall be a federation in which regions or province enjoy complete autonomy.

Each belligerent hopes a decisive military victory. According to this write, it is not possible. Tehran will likely continue to support Assad until some leaders come along who is willing to have friendly relations with Iran.

In the past major powers tried to broker a peace agreement without success. Even the UN Security Council failed to bring any acceptable 


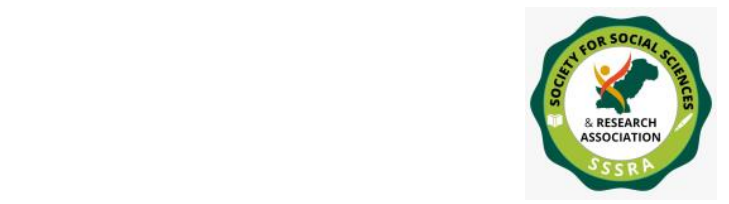

Pak. Journal of Int'L Affairs, Vol 2, Issue 1 (2019)

Syrian Civil War in International...

solution to this problem. It called for a cease fire, provision of humanitarian aid, drafting of a new constitution and holding a fair election under UN supervision.

The reasons for failure are obvious. The major powers especially the United States and Russia did not agree on major issues. The issue is should ASSAD be allowed to stay in power? If Assad is removed or overthrown should he be allowed to take part in the election? The other relevant questions are which rebel groups be included in the peace process and which group should be defeated and removed from the peace process Keep in view the fragile, horrific and volatile picture of the Syrian civil war, there is great that Syria may fragmented. It may be divided into many regions. No rebel group apprehension has the military power, the its control. Most Syrians do not want their country divided.

Syria poses a profound dilemma. An intervention that simply removes Assad, as Libyan removed Gaddafi, creates new and different problems for the Syria people, and these new problem be more intractable. Strengthening ISIS would be just one of the possible unintended consequences, but likely more dangerous Jessica and Berger, J.M. (2016, P254)

A federation of autonomous units or regions seems to be acceptable and viable solution. The Sunnis, the Shiites, the Duuz, the Kurds, the Alawites all claim to be Muslims. The Christians are no more than 10 per cent in the country. Logically, therefore the country can be called Islamic republic. Those plead for secularism have no moral grounds. Assad claims to be a secularist. Russia, Iran and Hezbollah are extending military support to Assad. Yet there is no chance of their success. All rebel groups are fighting against Assad who represents secularists.

Constitution of the future Republic of Syria will be drafted by popularly elected assembly. This constitution should guarantee the freedom of minorities in their personal laws. Once the world powers and the regional powers agree to a peaceful settlement, the terror of the ISIS and Al-Qaeda will vanish. Iran, Russia, Hezbollah cannot expect any victory. Their 
sphere influence and nature of influence will be greatly reduced. Saudi Arabia along with the Western alliance is likely to emerge as victorious. If it is not outright victory for any party. Saudi influence will greay enhance. 


\section{REFERENCES}

Ahmad, S. S. Sheikh, Riaz. (2007). Terrorism A Grim Challenge to Social science. BIZTECH Journal,

Andrews, John. (2016). The World in Conflict. New York, NY: The Economics.

Bennett, Andre and Sham Baugh, George. (2006). Taking Sides: Clashing view on Controversial Issues in American Foreign Policy. Dubuque: OWA The McGraw Hill Companies.

Brunet-Jailly, Emmanuel (ed.) (2015). Border Disputes. A Global Encyclopedia., Santa Barbra: ABC-CLIO.

Colvocressi, Peter. ( 1993). World Politics Since 1995. New York,NY: Longman Publisher.

Erlich, R. (2016). Inside Syria: The Backstory of Their Civil War and What the World Can Expect New York, NY: Prometheus Books.

Kennedy, Paul. (1998). The Rise and fall of the Great Powers. USA: Random House.

Said, Edward W.(1992) The Question of Palestine. Beirut: Vintage.

Stern, Jessica and Berge JM. (2016). ISIS: The State of Terror. New York, NY: Harper.

Warrick, Joby. (2016). Black Flag: The Rise of ISIS. New York, NY: Anchor Books Services Club Collins Publishers. 